\title{
INTELECTUAIS, HISTÓRIA E PENSAMENTO BRASILEIRO: ESCRAVIDÃO, TRABALHO E EDUCAÇÃO NO “AMÉRICA LATINA - MALES DE ORIGEM" DE MANOEL BOMFIM ${ }^{i}$
}

\author{
Jean Carlo de Carvalho Costai \\ Universidade Federal da Paraíba \\ jeanccosta@yahoo.com.br \\ Amanda Galvíncio iii \\ Universidade Federal da Paraíba \\ amanda_galvincio@ hotmail.com \\ Maíra Lewtchuk Espindola ${ }^{\text {iv }}$ \\ Universidade Federal da Paraíba \\ mairalewtchuk@hotmail.com
}

\section{RESUMO:}

O período da escravidão é entendido por intelectuais brasileiros entre os séculos XIX e $\mathrm{XX}$, como um momento "torpe" da nossa história, reconfigurada, porém, essa visão ainda persiste, no período pós-escravocrata. Dentre estas, destaca-se a de Manoel Bomfim (18681932) e o seu "A América Latina: males de origens" (1905). Bomfim argumenta que o trabalho escravo, implantado na América do Sul, pelas metrópoles Ibéricas, estava estreitamente ligado ao processo parasitário dessas nações. A tese do "parasitismo social" é central na obra desse autor, pois é a partir dela que ele elabora uma interpretação ancorada nas noções de 'dominador' e 'dominado', tendo a ela subjacente a idéia de compreender os processos formadores da nacionalidade dessas sociedades. A condição imposta pelo trabalho escravo gerou efeitos desastrosos a essas nações, trazendo à baila implicações históricas perniciosas a sua "vida econômica, política, social e moral", pois, a esses indivíduos, era negada a realização de um "trabalho inteligente", na medida em que não se proporcionou uma educação para a criação de uma "população agrícola rural, ativa, laboriosa, educada e fortalecida pelo trabalho". O argumento central deste artigo é o fato de que esses "efeitos gerais" causados pelo "parasitismo" influenciaram o descompasso existente entre as nações Sul- Américas e as nações denominadas "adiantadas", sendo a educação o diagnóstico que minimizaria esse hiato.

Palavras-chave: Intelectuais. Educação. Trabalho e parasitismo social.

\section{INTELLECTUALS, HISTORY AND BRAZILIAN THOUGHT: SLAVERY, WORK AND EDUCATION IN “AMÉRICA LATINA - MALES DE ORIGEM” OF MANOEL BOMFIM}

\begin{abstract}
The period of slavery is understood by Brazilian intellectuals of the nineteenth and twentieth centuries, as a moment "vile" in our history, reconfigured, however, still persistent in the post-slavery. Among these, stands out Manoel Bomfim (1868-1932) and his "Latin America: origins of evil" (1905). Bomfim argues that slave labor, deployed in South America, the Iberian cities, was closely associated with the parasite of nations. The thesis of "social parasitism" is central to the work of this author, it is from there that he draws an interpretation rooted in the notions of dominant and dominated, taking her behind
\end{abstract}


the idea of understanding the processes that form the nationality of those companies. The condition imposed by slave labor produced disastrous effects of these nations, bringing to light the historical implications of their pernicious "economic, political, social and moral," because these individuals were denied the creation of a "working smarter" in far as not provided an education for the creation of a "rural agricultural population, active, industrious, educated and strengthened by the work." The central argument of this paper is the fact that these "general effects" caused by free-riding influence the gap between the nations of South America and the nations as "early", with education being the diagnosis that would minimize this gap.

Keywords: Intellectual. Education. Work and social parasitism.

A pessoa que não consegue enfrentar a vida sempre precisa, enquanto viva, de uma mão para afastar um pouco de seu desespero pelo seu destino [...] mas com sua outra mão ela pode anotar o que vê entre as ruínas, pois vê mais coisas, e diferentes, do que as outras; afinal, está morto durante sua vida e é o verdadeiro sobrevivente.

Franz Kafka.

Em obra hoje clássica, o escritor italiano Ítalo Calvino nos convidou a "ler os clássicos" e nos indagar da importância deles. Em seu Por que ler os clássicos (1993), ele argumenta que nenhum livro que fala de outro livro diz mais sobre o livro em questão. Por um lado, ele nos chama a atenção para o fato de que a crítica subsequiente não substitui a leitura da obra em um instante temporal futuro; por outro, no entanto, a leitura a partir do olhar do presente, inevitavelmente, nos conduz a esclarecimentos, a detalhes, ao desvelamento de elementos empoeirados ou mesmo nublados pelo olhar da historiografia, ou seja, nos conduz a reconfigurar hipóteses interpretativas sobre a obra e, quiçá, identificar os "lampejos" sobre os quais nos fala Walter Benjamin (1892-1940), em clássico ensaio sobre o conceito de história.

Essa reconfiguração metodológica, a partir de uma "leve" crítica à concepção de Calvino, nos leva à idéia de intérprete que, do ponto de vista da hermenêutica crítica gadameriana, de certo modo, guia a inserção no texto de Manoel Bomfim. Para HansGeorg Gadamer (1997), o intérprete encontra-se numa "situação hermenêutica" que corresponde a suas idéias preconcebidas resultantes de sua relação com a tradição. Toda interpretação inicia-se com essas idéias preconcebidas que devem ser investigadas em sua origem e valor. Ou seja, é a partir dessas "pré-concepções" que o intérprete formula seu projeto que antecipa um sentido em relação ao objeto, como totalidade. Essa antecipação, por sua vez, se confirma ou não em confrontação com a análise específica das partes desse mesmo objeto de conhecimento, em uma espécie de movimento concêntrico (ROHDEN, 2002), basilar da idéia de círculo hermenêutico, em que a interpretação parte de uma antecipação do todo que se atualiza no conhecimento das partes, validando a antecipação inicial e voltando às partes. Aqui, na verdade, para o intérprete, a compreensão da ação, e aqui argumentamos a similaridade entre ação e texto (RICOUER, 1986), não é nem uma 
apropriação dos conceitos dos atores nem a imposição das categorias dos intérpretes, mas uma fusão dos dois numa entidade distinta: a interpretação (HEKMAN, 1986).

Ora, nos século XIX e início dos XX, muitas teses foram geradas a partir da condenação da instituição escravista, que no caso do Brasil duraram trezentos anos. A escravidão era vista como incompatível aos preceitos liberais aclamados na Europa desde o século XVIII. Com a revolução burguesa são criados novos conceitos, esses atacavam o Antigo Regime (tradicional), criticavam a teoria que atribuía aos reis um poder divino e proclamava a soberania dos povos, exigindo a criação de formas representativas de governos; além de, instituírem as leis e os direitos naturais dos homens: a propriedade, a liberdade e igualdade de todos. É nesse arcabouço teórico que a escravidão começa a ser combatida e apontada como o mal a ser regenerado perante a humanidade (COSTA, 2008 [1981]).

Os intelectuais desse período ocupavam-se das discussões que, no Brasil, estavam atreladas à queda do Império, fim da escravidão e início da Republica. Este artigo tem como objetivo central dá destaque principalmente a Manoel Bomfim (1868-1932) que, como outros, viram na instituição escravagistav ${ }^{v}$, um dos principais impedimentos econômicos diante do 'progresso' e da inserção do Brasil na "modernidade" (ORTIZ, 1994 [1985]), a qual, em alguns outros centros, já se encontrava em "aventura" deveras acelerada (BERMAN, 1986). Bomfim é responsável por uma espécie de "interpretação dissidente" entre os homens de letras do período, seguindo expressão utilizada por Renato Ortiz (1994 [1985]), cujo eixo é a crítica elaborada por ele ao diagnóstico do "atraso brasileiro", essencialmente, basilado em elementos raciais, eivados de pré-conceitos gestados sob a égide de torpes argumentos parasíticos colonialistas.

A interpretação bomfiniana do "atraso", por décadas, foi considerada interpretação "marginal" e a sua figura associada à profícua expressão de Ronaldo Conde Aguiar, em seu trabalho doutoral, Manoel Bomfim, "o rebelde esquecido" (AGUIAR, 2000). Na transição entre os séculos XX e XXI, de modo gradativo, não mais esquecido, mas sim recolocado entre os "principais intérpretes do Brasil" e, ainda, sobre persistente interesse acadêmico, estendendo-se do âmbito da História e da própria historiografia ${ }^{\text {vi }}$, perpassando a Sociologia, a área das Relações Internacionais e da Ciência Política, Educação e Geografia (AGUIAR, 2000; BOTELHO, 2003; GONTIJO, 2003; COSTA, 2005, 2008; UEMORI, 2006; PRIORI, CANDELORO, 2009). Esse interesse, ainda não esgotado, recoloca o pensamento bomfiniano em posição de profunda inovação, isso porque, em grande medida, a sua interpretação do nacional é fortemente contrária a um tipo de "utilização" dessas perspectivas teóricas dominantes no pensamento social brasileiro de então, cuja base era formada pelas teorias sociais européias basiladas no pensamento darwiniano que parecem ter "coroado" o ápice da modernidade ocidental e, em especial, a brasileira (SCHWARCZ, 1993) ${ }^{\mathrm{vii}}$.

Manoel Bomfim (1868-1932), cuja obra é elaborada especialmente na Primeira República, tem a sua inserção nos debates intelectuais da época através de seu diálogo crítico com algumas das principais questões que inquietavam a transição do Império à República que, a despeito da aparente ruptura política, traduzida através da idéia de "superação do Regime Imperial" e de um de seus maiores cancros, a Instituição Escravista, parecia não ter efetuado mudanças que levassem o país em direção ao progresso tão desejado por alguns intelectuais engajados nas lutas abolicionistas e antimonárquicas, originando, daí, certa crítica ao "paradigma republicano" (ROCHA, 2004). Bomfim, um dos representantes dessa geração crítica pós-Geração 1870 (ALONSO, 2002), formula um diagnóstico para dar conta de explicar como o processo histórico dessas nações estava imbricado por um "elemento em comum", e por isso, 'travou' esses povos levando-os à 
desorganização social, política e moral. O elemento em comum apontado pelo autor está no processo pelo qual essas sociedades foram formadas. E, para tanto, baseou seus argumentos nos pressupostos evolucionistas que em sua época influenciaram várias teses ${ }^{\text {viii }}$ sobre o "atraso brasileiro", e nas analogias entre organismos biológicos e organismos sociais, utilizando-se da metáfora "parasitismo social", que se pode identificar como idéia central em sua obra.

No argumento de Bomfim, em uma das primeiras análises comparativas internações no contexto sul-americano ${ }^{\text {ix }}$, a América Latina encontrava-se em descompasso com a marcha da evolução social, refletindo nas economias nacionais o mal estar gerado pelo trabalho escravo, que por muito tempo havia sustentado a economia dessas nações. Para ele, essa situação perpetuava-se, ou usando seu próprio termo, era passado por "hereditariedade" para caráter nacional das novas nações ${ }^{\mathrm{x}}$. Sua hipótese trata a escravidão como efeito do parasitismo social imposto no processo de colonização ibérico, e, este teve como alvo principal de ataque a economia das sociedades em formação. Ou seja, para Bomfim:

São os efeitos econômicos os mais sensíveis nesse regime de colonização parasitária. Pode-se mesmo dizer que são os efeitos primordiais, aos quais se ligam os outros como secundários. Em si, o parasitismo das metrópoles, como o parasitismo social em geral, é um fenômeno de ordem econômica, cujos efeitos se refletem sobre toda a vida social (BOMFIM, 1993, p.127).

Para apreender a "obra da escravidão" em Manoel Bomfim, debruçamo-nos no América Latina: males de origem, na intenção de compreender o ponto de vista e as análises desenvolvidas pelo autor, que nas palavras de Darcy Ribeiro, Franklin de Oliveira, Azevedo Amaral, em seus comentários à Edição publicada em 1993, produziu uma interpretação "original e madura sobre a realidade da America Latina". Entender o porquê dessa originalidade é, de certo modo, o objetivo dessa intervenção e do processo investigativo que a originou.

A delimitação deste artigo pretendeu examinar a questão do "trabalho escravo" e os desdobramentos negativos na formação dessas nações, e a sua proposta de superação via Educação. Para tanto, iremos reconstruir a interpretação bomfiniana sobre o tema a partir de alguns conceitos centrais em sua obra, que sintetizam como esse autor do início do século XX propôs soluções baseadas na "instrução popular" para o impasse das sociedades sul-americanas em um contexto de embates inter-nacionais em torno da idéia de "formação nacional" e "soberania política".

\section{O nacional entre a raça e a instrução no pensamento brasileiro do XIX}

As discussões em relação ao "fenômeno naciona" permeiam todo o pensamento social no Brasil, talvez com certa hegemonia que compreende desde o predomínio da "bricolage de uma identidade nacional" elaborada pelo romantismo brasileiro ( ORTIZ, 1994 [1985], p. 19), que pode ser situada em torno de 1870 até a 'virada culturalista' proporcionada pela obra de Gilberto Freyre (1900-1987), na década de 1930, particularmente a partir de seu Casa-Grande \& Senzala (FREYRE, 2001 [1933]), considerado por alguns a "Paidéia de um Werner Jäger dos trópicos" (CHACON, 2001, p. 39). 
No intervalo que compreende as últimas décadas do século XIX e meados da década de 1910, as tentativas de interpretar o nacional são conduzidas a partir da possibilidade percebida de articulação dos conceitos de "raça" e "meio", com o objetivo de encontrar uma espécie de via alternativa cujo eixo preservaria a "singularidade sócio-racial brasileira"; entretanto, essas tentativas são guiadas, do ponto de vista teórico, por uma perspectiva determinista de cunho racial. De fato, considere-se o próprio termo 'miscigenação', cuja influência no discurso imperial e colonial contemporâneo é evidente em torno das referências negativas às uniões de 'raças' distintas (YOUNG, 1995), tendo passado a ser, inevitavelmente, na virada dos séculos XIX-XX, parte do discurso colonialista do racismo.

No Brasil, o 'fenômeno nacional' adquire enorme importância na segunda metade do século XIX, especialmente através do pensamento de alguns intelectuais brasileiros como, por exemplo, Sílvio Romero (1851-1914), embora seja necessário afirmar que estas inquietações não constituem privilégio dessa época, tendo permeado toda a história da formação da nacionalidade brasileira (CANIELLO, 2001). Entretanto, talvez seja possível ressaltar o maior relevo a ele atribuído pelos "românticos", ainda que envoltos na perspectiva de revestir o elemento indígena em 'elemento civilizado', afirmando por completo a desimportância do negro na constituição da nacionalidade brasileira, o qual apenas torna-se parte inevitável da reflexão sobre a dinâmica social com o advento da Abolição.

Ora, verificando o contexto descrito, é possível dizer que duas perspectivas relativamente hegemônicas, e uma à época "marginal", de interpretação do Brasil, no tocante ao entendimento do 'nacional', destacaram-se no início do século, tendo o constructo 'raça' predominância no caráter definidor da nacionalidade, cuja consequiência, haja vista o tipo de 'teoria social' produzido no período, é uma espécie de ruptura do campo intelectual, talvez um dos elementos explicativos da 'marginalização' de determinadas interpretações.

De modo geral, no pensamento social brasileiro, a temática em questão foi abordada por alguns dos principais ensaístas cuja obra, de um modo ou de outro, inevitavelmente, percorreu as relações entre 'nacionalidade' e 'raça' na busca pela explicação do fenômeno nacional. De fato, por um lado, temos a referência primordial ensaísta de influentes intelectuais como o já citado Sílvio Romero (1851-1914), Euclides da Cunha (1866-1909) e Oliveira Vianna (1883-1951) e, de modo mais indireto, o famoso ensaio de Paulo Prado (1869-1943), 'Retrato do Brasil' (1997 [1928]), especialmente o seu Post-Scriptum que, seguindo princípios e idéias 'evolucionistas' e 'deterministas' relativas à 'degeneração', 'barbárie', 'miscigenação' e 'enfermidade social', debruçaram-se sobre a problemática racial, levando-os, de modo geral, à crença no princípio de que o único modo de resolver o "problema' seria através do cruzamento racial, o que desemboca na conhecida 'teoria do branqueamento', uma das peculiaridades tipicamente nacionais, e na ênfase nas políticas de imigração e de educação, ou seja, em direção ao triunfo e à regeneração da raça branca no país (VENTURA, 1991; SCHWARCZ, 1993).

Outra vertente, contrária a um certo otimismo que perpassava o pensamento de certos autores em relação ao papel da raça, era constituída por outros intelectuais que, mais críticos em relação ao 'valor social' do mestiço, consideravam o cruzamento racial um verdadeiro perigo para a boa saúde do Brasil e da etnicidade branca. Entre eles, talvez o de maior destaque seja o médico baiano Raimundo Nina Rodrigues (1862-1906), cujas pesquisas sobre a influência africana e o sincretismo religioso no Brasil, inovadores estudos etnográficos na época, tenderam a fortalecer as suas concepções racistas e a crença na tese da degeneração racial como conseqüência da mestiçagem. 
No intermédio entre esses dois 'projetos para o Brasil' tem-se a 'interpretação dissidente', seguindo expressão utilizada por Renato Ortiz (1994 [1985]), do sergipano Manoel Bomfim (1868-1932), interpretação 'marginal' à época, a qual nos referimos. Bomfim, o 'rebelde esquecido' (AGUIAR, 2000), tem sido, de modo gradativo, especialmente nos últimos quinze anos, recolocado entre os "principais intérpretes do Brasil", inclusive em posição de enorme inovação, isto porque, em grande medida, a sua interpretação do nacional é fortemente contrária às perspectivas teóricas dominantes no pensamento social brasileiro de então, cuja base era formada pelas teorias sociais européias (Darwinismo social, evolucionismo e o positivismo), tríade teórica fundamental que, de certo modo, parece ter 'coroado' o ápice da modernidade ocidental.

De modo geral, é importante realçar que a ambigüidade e elementos contraditórios são efetivamente correntes nos ensaios interpretativos dos intelectuais que pensaram o Brasil àquele período, produto, em grande parte, da incompatibilidade percebida entre a "tríade teórica" hegemônica à época e a realidade que ela deveria "explicar" (ORTIZ, 1994 [1985]), não diminuindo, no entanto, a sua importância:

Há uma conexão mais ou menos estreita entre os seus modos de abordar o Brasil e o nacionalismo sistemático [...] do próprio Estado Novo. É arriscado, porém, incluí-los genericamente entre os ideólogos da Direita, em razão do colorido opressor, classista e racista que o termo foi assumindo por força das vicissitudes políticas do século XX. Representam, em conjunto, um sintoma da crise do liberalismo jurídico abstrato, da sua incapacidade de planificar o progresso de um povo; e, apesar das suas diferenças e mesmo das contradições internas de que todos padecem, significam [...] um passo adiante na construção de uma sociologia do povo brasileiro (BOSI, 1994, p. 313, grifo nosso).

De fato, são os efeitos de suas obras no diálogo entre as mudanças na teoria social contemporânea e o processo de globalização, posterior a essa erupção ensaísta, que confirmarão ainda mais a sua importância, por um lado, devido ao fato de que "os contemporâneos muitas vezes são os piores intérpretes de uma obra" (SCHNAIDERMAN, 2000, p. 9) - a desimportância histórica atribuída, por exemplo, a Manoel Bomfim, pode ser uma dessas piores interpretações - e por outro, porque muitos de seus desmembramentos transformaram-se em "programas de organização sócio-política".

Ou seja, pode-se dizer, neste sentido, que, por exemplo, o desdobramento, do ponto de vista estético e ideológico, do Modernismo brasileiro nos anos de 1920 "veio criar condições para aproveitar e desenvolver as intuições de um Sílvio Romero, ou um Euclides da Cunha, bem como as pesquisas de um Nina Rodrigues" (CANDIDO, 2000 [1965], p. 123). Além disso, não é à toa que é característico desse período o fato de ele tender ao ensaio, não apenas às breves crônicas como ao longo ensaio histórico e sociológico, que, de certo modo, incorporou o movimento ao pensamento nacional.

Diante de tais esclarecimentos, haja vista que já vão longe estes prolegômenos, oferecemos ao leitor, na seção seguinte, alguns elementos do pensamento de Manoel Bomfim, hoje considerados 'inovadores', que podem ser interpretados como o reflexo, na esfera local, da 'redescoberta' do nacional a partir das inquietações presentes nas discussões contemporâneas relativas à teoria social e à estrutura social. 


\section{Os "lampejos" de Manoel Bomfim no pensamento brasileiro contemporâneo}

Manoel Bomfim (1868-1932) pode ser considerado hoje um dos intelectuais mais importantes do pensamento social brasileiro, ainda que, em muitos textos onde a sua obra poderia exercer papel relevante ao ser confrontada com certas interpretações, é deixada de lado ou é permitida a ela espaço não correspondente em importância. De fato, por exemplo, Leite 1992 [1954] ressalta que obras, à época, recentes, relativas à história da literatura brasileira, como as produzidas por Wilson Martins (1965) e Alfredo Bosi (1966) não citam Manoel Bomfim, 'salvo erro, uma só vez'; em Nelson Werneck Sodré (1969), são lembrados 'aspectos positivos de sua obra', especialmente o fato de ter efetuado uma espécie de análise marxista em seu diagnóstico do 'atraso' brasileiro; entretanto, quando compara-se o empreendimento de Bomfim e a atenção dada as obras de Oliveira Vianna e Paulo Prado, autor de Retrato do Brasil. Ensaio sobre a tristeza brasileira (1997 [1928]), Bomfim torna-se insignificante. Mais recentemente, tem-se Thomas Skidmore, talvez dos autores estrangeiros, brasilianistas, que 'pensam' o Brasil, aquele ao qual mais recorreram os intelectuais brasileiros nas últimas décadas, tem em um de seus livros publicados no país, O Brasil visto de fora (1994), um capítulo que se denomina "Criadores de mitos: os arquitetos da identidade nacional brasileira", onde ele faz uma síntese de intérpretes do Brasil, transitando de Sílvio Romero a Darcy Ribeiro e Roberto DaMatta sem, no entanto, dedicar uma linha à obra de Manoel Bomfim. Outro autor, Kabengele Munanga (1999), em um texto 'quase similar' ao de Skidmore, onde ele discorre sobre como o tema 'mestiçagem' foi tratado no pensamento social brasileiro, dedica cerca de 14 páginas à uma análise da obra de Oliveira Vianna, inclusive dando um certo destaque a sua 'Teoria do Estado', e não alcança uma página completa tratando da obra de Manoel Bomfim, tanto à sua posição sobre a tese degenerativa dos cruzamentos raciais quanto à sua teoria do Estado.

Além disso, em alguns dos seus intérpretes contemporâneos, especialmente os que sobre o pensamento social no Brasil se debruçaram nas décadas de 1970 e 1980, é possível identificar alguns equívocos relativos à sua obra devido a certo desconhecimento e também à importância ainda pouco atribuída à sua contribuição à constituição do pensamento brasileiro. O seu livro mais importante, América Latina: males de origem (1993 [1905]), por exemplo, foi citado por alguns de seus intérpretes, Skidmore, Darcy Ribeiro e Renato Ortiz, como tendo sido publicado em 1903, devido ao fato de que a sua primeira publicação curiosamente não era datada, embora intérpretes anteriores, como Dante Moreira Leite, em seu texto clássico ora mencionado e publicado em 1954, o tenha citado corretamente. Contudo, é importante salientar que a edição, por exemplo, utilizada por Ortiz, Editora A Noite, não apresenta data de publicação.

Entretanto, também é possível afirmar que a partir da última década tem-se percebido um gradual aumento de interesse por sua obra, especialmente a partir da emergência, no Brasil, de alguns de seus mais importantes trabalhos. Além disso, recentemente, houve a publicação de uma excelente biografia ${ }^{\mathrm{xi}}$, cuja leitura em muito auxilia o entendimento de seus escritos e também proporciona um importante diálogo crítico com as leituras efetuadas por alguns de seus intérpretes. De modo geral, parece que essa mudança de importância atribuída a determinados intelectuais brasileiros, no mínimo, representa uma leitura mais cuidada de suas teses que, de certo modo, podem fornecer uma maior compreensão de seus conteúdos e a sua importante interpretação da tradição nacional, haja vista que alguns deles elaboraram uma representação do Brasil menos forçosamente hegemônica, algo que se contrapõe à unilateralidade teórica que 
caracterizaria ou que definiria a intelligentsia brasileira no início do século XX (SKIDMORE, 1976) ${ }^{\mathrm{xii}}$.

De certo modo, pode-se dizer que o esquecimento ao qual ele próprio e o seu principal livro, A América Latina: males de origem (BOMFIM, 1993 [1905]), foram expostos ao longo do século XX, seja atribuído a um conjunto de elementos inevitavelmente inter-relacionados. Esses se encontram, por um lado, vinculados à, hoje, consensual originalidade de seu trabalho, o que o afastava do discurso hegemônico da época, ou seja, "a razão fundamental para o esquecimento de sua obra decorre do fato de "Manuel Bonfim estar adiantado com relação aos intelectuais de seu tempo" (LEITE, 1992 [1954], p. 251, Grifo nosso) ou "à frente do seu tempo ao rejeitar as doutrinas das diferenças inatas entre as raças" (SKIDMORE, 1976, pp. 130-131); por outro lado, ao 'espírito apaixonado' que o movia, elemento que inclusive foi curiosamente um dos alvos principais de seu crítico mais conhecido, o 'Sr. Sílvio Romero', cuja famosa atividade de crítico, se é possível o uso de tal conceito àquele contexto histórico, era fervorosamente apaixonada.

O 'esquecimento' de Bomfim, sem dúvida, relaciona-se com o pensamento e a posição ocupada no campo intelectual da época pelo também sergipano Silvio Romero. Os argumentos de Sílvio Romero à sua obra versavam, primeiro, sobre a sua 'parcialidade', elemento intimamente contrário aos princípios cientificistas da época, inclusive devido em parte pela influência decisiva que a suposta 'objetividade' associada ao uso da Estatística exercia no pensamento brasileiro ${ }^{\text {xiii }}$. Dante Moreira Leite, um dos intérpretes clássicos de Bomfim, acreditava ter sido essa, a parcialidade, a causa do fato de ele ter sido "incapaz de colocar-se na perspectiva histórica para julgar homens e acontecimentos do passado" (LEITE, 1992 [1954], p. 251) e, segundo, o fato de Bomfim ter se atrevido a "refutar teorias cientificamente provadas" como as dos "venerandos pensadores Gustav Le Bon e Gobineau" (ROMERO, 1906, p. 233).

Uma observação parece ser relevante em relação ao primeiro aspecto. De certo modo, parece haver uma certa injustiça no texto de Dante Moreira, haja vista que a suposta "parcialidade" de Bomfim não o impede de alicerçar os seus argumentos em consonância com as tendências mais contemporâneas da época, que emergiam em oposição àquelas já tornadas hegemônicas, fato que é observado por vários de seus intérpretes posteriores (SKIDMORE, 1976; ORTIZ, 1994 [1985]). Ou seja, a "paixão" em Bomfim não o impossibilitou deixar de lado o seu envolvimento emocional em desejar re-elaborar, de modo coerente, a história do Brasil ${ }^{\text {xiv }}$.

Ao contrário, em uma das notas críticas em seu A América Latina ao historiador português Oliveira Martins (1845-1894), que no Brasil possuía ilustres discípulos (MALATIAN, 2001), como o historiador-diplomata Oliveira Lima (1867-1928), Manoel Bomfim recorre, por um lado, a inúmeros antropólogos contemporâneos a ele, Zaborovski, Quatrefages e Topinard, que ressaltavam "o sentido lingüístico e não racial de ariano", "raça" essa correntemente alvo de apologias ${ }^{\mathrm{xv}} \mathrm{e}$, por outro, tratou de implementar a sua defesa apaixonada pela obra de Darwin que, segundo Bomfim:

Nunca supôs que a sua obra genial pudesse servir de justificação aos crimes e às vilanias de negreiros e algozes de índios!... Ao ler-se tais despropósitos, duvida-se até da sinceridade desses escritores; Darwin nunca pretendeu que a lei da seleção natural se aplicava à espécie humana, como dizem os teoristas do egoísmo e da rapinagem. Ele reconheceu que os seres vivos lutam pela vida; mas esta expressão 'luta' não tem, na teoria, o sentido estreito a que reduzem os espíritos acanhados; luta pela vida quer dizer, para ele, tendência a viver, esforço 
para conservar a vida e propagá-la, e não, simplesmente, conflito material, agressão cruenta (BOMFIM, 1993 [1905], p. 249, grifo nosso).

Ao ler o excerto acima se percebe como, de fato, uma das características principais do texto de Manoel Bomfim, especialmente o seu A América Latina, é a sua condução pela "paixão" por um país e por um continente, algo que, do seu ponto de vista, não impedia o rigor da lógica, haja vista a sua menção a autores que expressavam posições distintas do imperialismo determinista da época; por isso é que, em seus próprios termos, a sua principal obra:

É um livro nascido, animado, alimentado e divulgado pelo sentimento; não o sentimento dos interesses pessoais, que obscurecem a razão e pervertem o julgamento, mas um sentimento que só aspira alcançar a verdade - a causa efetiva desses males, dentro dos quais somos todos infelizes, o desejo de subir à civilização, à justiça, a todos os progressos (BOMFIM, 1993 [1905], p. 35).

Nesse sentido, pode-se dizer que, na esteira da preocupação central que instigou os intelectuais brasileiros da Geração de 1870 "à luta" (VENTURA, 1991), a saber, a problemática da identidade nacional em face das diferenças raciais do povo brasileiro, os objetivos de Bomfim encontram-se associados, de modo geral, a dois elementos.

Em primeiro lugar, a pensar "a pátria, com as particularidades próprias da sua formação histórica”. Nesse instante, parece não haver nada de novo quando ele é comparado aos intelectuais da mesma época, mas, a partir daí, em nosso entendimento, percebe-se a sua originalidade no tratamento do diálogo entre o local e o global, fonte de possíveis relações entre a sua obra e os motivos de sua revalorização contemporânea: pensar a pátria "inserida na América. e como parte integrante da humanidade" (AGUIAR, 2000, p. 303). De fato, o próprio Renato Ortiz (1994 [1985]) ressalta que Bomfim foi o primeiro pensador brasileiro a refletir sobre a problemática nacional em esfera mais ampla, ou seja, tratando-a "enquanto parte de um sistema mais abrangente, o da América Latina, a questão nacional se reveste de uma especificidade política mais geral, pois se perguntar sobre o Brasil equivale a se indagar a respeito das relações entre América latina e Europa" (ORTIZ, 1994 [1985], p. 23).

Essa forma de interpretação do fenômeno nacional, nos dias de hoje, já é amplamente conceituada, por exemplo, o sucinto e instigante, hoje já clássico, texto de Octavio Ianni, O labirinto latino americano (1993), expressa, na contemporaneidade, elementos comuns que constituem o pensamento social e a realidade do continente, reflexo da compreensão "universalista" e "globalizada" inaugurada por certos autores clássicos como Manoel Bomfim.

Em segundo lugar, um dos objetivos de Bomfim é, sem dúvida, recusar a percepção hegemônica da intelligentsia brasileira de então de atribuir o 'atraso brasileiro' à inconsistência dos elementos biológicos, alicerce das teorias sociais européias que forjaram a base do racismo científico, tipificando essa forma de pensar como expressão de um discurso dominante que apenas visava legitimar interesses colonialistas europeus na América Latina, ou seja:

[...] Bomfim procurou dar uma resposta aos teóricos e publicistas europeus que, apoiados no cientificismo naturalista e no evolucionismo, chamavam, indistintamente, os povos do continente de inferiores, entregues, segundo afirmavam, ao mais puro barbarismo estéril. A América Latina seria, em consequiência, este imenso território povoado 
de gente selvagem e inferior, uma mistura de descendentes de índios, negros e degradados, todos inatamente incapazes de autogovernar-se e autodefinir-se como povos soberanos. Segundo os teóricos e publicistas europeus, a pretensa homogeneidade dos povos latino-americanos residia no fato cientificamente inconteste de que todos estavam condenados ao atraso, não lhes restando outro caminho que o da submissão passiva aos povos superiores (AGUIAR, 2000, p. 305, grifo nosso).

\section{A República, a "obra da escravidão" e a idéia de trabalho}

A escravidão no América Latina: males de origem recebeu uma importância expressiva, pois, é a partir das análises sobre o trabalho escravo que Bomfim definiu o "caráter do trabalhador nacional". A despeito da crítica radical bomfiniana ao papel da escravidão e de suas conseqüências, isso não ocorreu de forma isolada, sendo tema presente desde as primeiras incursões pré-Abolição na intelligentsia nacional, adquirindo entonação em vários debates da época, que viam na base de uma sociedade escravocrata, o atraso 'moral e econômico' do país, prototipizada na hoje mítica narrativa de Joaquim Nabuco (1849-1910), (SALLES, 2002) ${ }^{\mathrm{xvi}}$. Ainda que se possa argumentar em torno da desimportância ou secundarização do papel dos intelectuais nesse processo (AZEVEDO, 2001, 2004, COSTA, 2008 [1981]), aqui, argumentamos em torno da não proficuidade de uma interpretação dicotomizada; ao contrário, há sim a participação dos intelectuais na expansão de reformas radicais, como por exemplo, a "democratização do solo", considerada "consequiência lógica pós-abolição" por muitos deles, bem como mobilizações periféricas de escravos que também contribuíram para o fortalecimento do processo abolicionista (SANTOS, 2000).

Manoel Bomfim se inseriu no debate como uma espécie de "herdeiro" dessa geração, que assimila os seus argumentos anti-escravagistas, mas, ao mesmo tempo, é crítico dela, basilando a sua abordagem da questão abolicionista na história torpe das nações sul-americanas tendo como elemento em comum o parasitismo ibérico exercido sobre as nações recém colonizadas. Portanto, em seus argumentos, o trabalho escravo estava ligado à submissão econômica e ao "monopólio mercantil" imposto por Portugal e Espanha, cujos únicos investimentos nessas nações foram as retiradas de riquezas e a degradação da população nativa (BOMFIM, 1993).

Esse argumento econômico foi trazido como eixo principal que mostrou a existência de uma estreita relação na exploração do trabalho escravo e na manutenção do aparelho colonial, que apontou para a escravidão como um dos sustentáculos do sistema consistindo na peça chave que fazia mover a máquina de lucro fácil da metrópole. $\mathrm{E}$, como conseqüência local, a formação de uma cultura trabalhadora alheia, desligada do processo de produção, desestimulada e desinteressada em desenvolver o "trabalho racional". Foi a partir desse eixo argumentativo que Bomfim definiu o problema do trabalhador nacional, ou seja:

Quando todo trabalho nacional era feito por negros e índios cativos, quando era possível haver escravo para tudo, não havia lugar para o trabalhador livre, a menos que ele quisesse trabalhar nas mesmas condições e pelo mesmo preço que o escravo- um salário tão insignificante quanto o custo da alimentação do negro,e a mesma obediência ao senhor. Quando não, esse ia ao mercado e trazia o negro. 
O trabalhador livre ficava ao lado. Foi assim que, de geração em geração, ele foi arredado do trabalho assalariado (BOMFIM, 1993, p.140).

A cultura do trabalho nas nações sul-americanas, ao invés de educar o homem, o consumiu, o devorou e afastou o trabalhador livre do processo de produção. Bomfim observou que o colonizador, ao perceber no trabalho escravo um negócio rentável, o instituiu, pois, para esse trabalho não era necessário averiguar-lhes as capacidades, ou, desenvolver tecnologias ligadas à produção, apenas lhes "bastavam alguns chicotes" para disciplinar o trabalhador e garantir-lhes os lucros. Sobre a colonização espanhola, por exemplo, afirma Bomfim:

Foi assim que a Espanha se formou; não há que separar o pequeno reino português - a história é a mesma. Oito séculos de luta contra o sarraceno, e, depois, ela aparece organizada, vigorosa, intrépida, unificada, possuída de um pensamento único: "conquistar o mundo", diz um dos seus panegiristas. Sim; e se ela o queria conquistar é porque o movimento adquirido a precipitava a isto: porque se habituara a viver exclusivamente do fruto das conquistas; porque não sabia fazer outra coisa senão guerrear; porque cultivara, intensamente, por onze séculos, os instintos guerreiros e agressivos, e guerrear se tornara para os homens uma necessidade orgânica. Porque em contato por oito séculos com o árabe depredador e mercantil, tomara gosto ao luxo e à riqueza facilmente adquiridas; porque aprendera com ele a ter horror e repugnância ao trabalho normal, sedentário, verdadeiramente produtor. (BOMFIM, 1993, p.81-82).

As explorações ibéricas nessas nações instituíram "males" profundos que afetaram de maneira desastrosa suas economias, o "parasitismo social" termo utilizado para ilustrar a relação colônia/metrópole, estava conectado tanto nas dimensões macro, que podia ser percebido pelo privilégio exclusivo metropolitano do comercio, quanto na dimensão das micro-relações diluídas nos interiores das colônias, relações estas, que estavam fixadas nos interesses materiais. (UEMORI, 2006). O escravo ficou, dessa forma, na ponta dessas duas realidades, pois, tanto o "sistema colonial" se beneficiava com o trabalho escravo quanto os senhores de terras locais. Para Bomfim, os escravos consistiriam nas "Vitimas das vitimas", e só quem trabalhava nas colônias eram eles:

Só o escravo trabalhava, só ele era produtivo: "nenhum braço português tocava os engenhos, nas roças de S. Tomé ou do Brasil". E com isto resultou que o trabalho foi considerado, cada vez mais, como coisa vil, infamante. $\mathrm{O}$ ideal para todos era viver sem nada fazer- ter escravos e ás custa deles passar a vida e enriquecer. (BOMFIM. 1993, p. 132).

As relações instituídas pelas sociedades escravocratas, além de envolverem a questão econômica, envolviam a população numa atmosfera psicológica de dependência mútua, pois, os parasitas como os parasitados estavam conectados pela sobrevivência, o parasita não sabe viver do seu próprio esforço laboral e para o parasitado só lhes restavam duas opções: ou ele se adaptava a vida ou morreria. Na obra de Bomfim, à dimensão psicológica se encontrava relativamente associada aos princípios da hereditariedade, os quais justificavam a conservação e harmonias da realidade estabelecendo certo equilíbrio social (UEMORI, 2006). Essa explicação pode ser utilizada para entender quando o autor 
cita a participação de negros e índios na defesa do território colonial, "Nas sociedades humanas, nós vemos os indivíduos das classes serem, não só explorados no seu trabalho pelos grupos das classes dominantes, como compelidos a defendê-los nas guerras, a elegêlos para cargos públicos." (BOMFIM, 1993, p.124).

A classe dirigente "conservou" o estado de coisas, opondo-se a qualquer tipo de mudança e progresso, dessa forma, quando chegou a Abolição e com ela, a instituição do trabalho livre, se percebeu que a igualdade jurídica conquistada com a Lei Áurea de 13 de maio de 1888, não era suficiente para transformar a realidade, que continuava perpetuando o seu "conservantismo sentimental", gerando dessa forma outras maneiras de dependência e exploração compulsória do trabalho, pois, os parasitados não tinham desenvolvido a capacidade para essas atividades.

Outro ponto que podemos acrescentar, na obra desse autor, é a denuncia da relação "desumana e violenta" dos senhores e escravos ${ }^{\text {xvii }}$, que foi relativamente secundarizada em algumas interpretações sobre a escravidão brasileira, isso porque, para outros, o brasileiro tinha um "caráter pacato", no entanto, para Bomfim(1993, p. 133):

[...] é a abjeção moral definitiva, a perversidade e a desumanidade permanentes: gerações e gerações de homens que viveram a martirizar, a devorar gerações de índios e de negros escravos- pela fome, o açoite, a fadiga [...] Não havia nada de humano nas relações senhor e escravo.

Essa questão ligava-se aos efeitos "morais" que passavam por tradição para a vida social das novas nações. Suas afirmações levaram em consideração que o caráter dessas sociedades foi "pervertido" pela instituição escravista, que se fazia presente no cotidiano da população e que de "geração e geração" cultuava o sofrimento do negro como algo comum e necessário. A escravidão foi justificada se baseando em pressupostos morais e econômicos, a primeira, sancionada pela igreja e pelo Estado, representantes de Deus na terra, portanto, de validade inquestionável. Os homens brancos e cristãos retiravam o negro da barbárie em que viviam, pois estes eram incapazes de sobreviver em liberdade. Em segundo lugar, do ponto de vista econômico, essa dependia exclusivamente da mão de obra escrava, e seu fim poderia significar a ruína para o país (COSTA, 2008).

Nessa época, era comum indicar propostas que tinham base nas reformas política e constitucional para superação da problemática girada em torno da escravidão e da economia. Porém, outros intelectuais, como Bomfim, argumentavam que os problemas incidiam na falta de incentivo à educação e à "universalização da instrução pública", pois, ao ser ver, "tudo está por fazer, a começar pela educação política e social da população" (BOMFIM, 1993, p.160).

\section{Educação, Reformas e a crítica ao republicanismo}

Ora, a idéia de "educação" aparece na America Latina: males de origem (1905), para articular e explicar como o "conservantismo das classes dirigentes" foi transmitido pela "tradição ibérica", justificando, nesse sentido, os programas políticos que tinham como característica principal o "egoísmo arvorado, e, enraizado no passado", que coibiu o progresso, perpetuou a desorganização social, e o regime retardatário, opressivo, corrupto e excludente. A essa classe foram feitas críticas severas, pois na prática esses homens, "escravos passivos da tradição e da rotina", resistiam a qualquer tipo de mudança real e progressista. Além do "conservantismo", faltava-lhe a sensibilidade de "observar a realidade"; era a partir da observação direta da vida, e das necessidades reais do povo, que 
estes deveriam preparar soluções que melhorassem a vida das populações. Contudo, estes se contentavam em fazer proclamações apoiados em "teorias gerais dos livros estrangeiros, ou com chavões e aforismos consagrados por esse senso comum, vão e antiquado; vindo de áreas defuntas, inspirados em causas estranhas" (BOMFIM, 1993, p.168).

Esta foi uma geração de intelectuais, que atualmente é conhecida como "Geração de 1870", pois, os mesmos compartilharam no período imperial colonial o que Ângela Alonso definiu como uma "comunidade de experiência", baseados na retórica e, nos interesses pela reflexão e experiência estrangeira, constituindo, assim, uma perspectiva comparada para dar conta de explicar e propor soluções para as crises políticas do período Regencial, para alguns, o mais conturbado deste século. A conseqüência desse processo de institucionalização da ciência no Brasil (SCHWARCZ, 1993), foi a gradativa solidez de uma espécie de elite política e intelectual, uma intelligentsia nacional, constituída por intelectuais de origem não popular. Bomfim argumentou que esta classe de intelectuais "revolucionários conservadores", poderia ser considerada tão conservadora quanto os conservadores de oficio, pois continuaram mantendo o estado de coisas:

Para esta classe, como para todo mundo, aqui, a ciência se reduz à leitura; as competências medem-se pelas bibliotecas, traduzem-se por discursos, e afirmam-se pela erudição. E como nenhuma cultura se faz pela observação das coisas, e como nenhuma produção intelectual se liberta da influência direta dos livros, não existe nenhuma originalidade, porque esta só existe para quem sabe inspirar-se na natureza, onde a novidade é constante. Não há espírito científico, nem pode haver; a leitura só da instrução, isto é, serve apenas para pôr o individuo ao nível da corrente intelectual da sua época; mas, em realidade, ela não educa a inteligência, porque não desenvolve o espírito de observação, não metodiza a elaboração mental, nem estimula a originalidade. Em resumo: a leitura é indispensável, mas não é o bastante (BOMFIM, 1993, p.170).

As críticas do autor estavam direcionadas aos intelectuais que ocuparam cargos públicos, a intelligentsia brasileira, que na sua ausência de observação só reproduziram códigos, discursos, tratados ou leis que podiam muito bem servir em qualquer parte do mundo. Foi no argumento de que as "leis" estavam desconectadas da realidade local, que podemos encontrar a questão central que articula o trabalho escravo e a próxima idéia de educação associada à "instrução popular e a educação para o trabalhador" no pensamento de Bomfim, uma espécie de ressonância, não presentificada àquele momento, das reivindicações de Joaquim Nabuco em torno da "universalização da instrução" alhures ressaltada (NABUCO, 2005).

Havia certo consenso entre alguns homens públicos que a escravidão atrapalhava a economia da nação, e por isso pediam-lhe o trabalho livre. Após a promulgação da Lei Áurea (1888), se encerou a responsabilidade do Estado perante aos escravos. Sua missão consistiu em libertar os homens brancos do peso da escravidão e das contradições que existiam entre trabalho escravo e os princípios liberais adotados desde a Constituição de 1824 , portanto, a questão jurídica não foi suficiente para eliminar as enormes distâncias sociais e os preconceitos que mais de trezentos anos de cativeiro havia criado, mas também não deixou de significar uma vitória para os negros (COSTA, 2008). Foram estas questões que, para Manoel Bomfim, precisavam ser re-formuladas, pois o bom desempenho da reforma não estaria somente pontuado nas "letras", mas na competência de examinar o evento e procurar os meios que garantissem eficiência da transformação na produção. Ele 
observou também que o trabalhador nacional, mais uma vez foi excluído do processo de produção, ora sendo acusado de indolente e inabilitado para o trabalho, ora sendo substituído por estrangeiros. Isto não acontecia por acaso, mas acabava garantindo que a estrutura social não se abalasse:

Pouco importam todas as qualidades de resistência e sobriedade que ele possui; pouco importa que lhes falte, apenas, a educação do trabalho e a instrução; foi condenado, e todos repetem a condenação, sem um instante de reflexão, sem atenuantes. É a sentença implacável, acompanhada com os panegíricos clássicos ao trabalhador estrangeiromuitos e longos elogios das miraculosas virtudes da imigração (BOMFIM, 1993, p.176)

O autor aponta para uma solução que, a seu ver, estava ligada à disseminação da escola primária e à educação voltada para o trabalho, ambas destinadas à classe popular. A questão central das classes inferiores não estava vinculada à inferioridade racial, mas a sua falta de educação. A função do Estado Republicano deveria ser de representante e defensor dos interesses gerais da população. Para isso, precisava garantir que o povo tivesse acesso à instrução primária e educação para o aperfeiçoamento da produção. Contudo, em certo sentido, a República herdou e conservou as ambigüidades derivadas dos embates entre conservadores e liberais gestadas no Império em relação à expansão e consolidação da instrução tanto em nível central quanto provincial (PINHEIRO, 2002), perpetuando a institucionalização do privilegiado ensino superior em detrimento do primário e popular, sendo que, mais tarde, a própria Constituição Republicana de 1891 só viria a reforçar estes princípios (ROMANELLI, 2007). Em síntese, o Estado, àquele momento, do ponto de vista da impressão bomfiniana, parecia se contentar em formar:

[...] doutores para boiar sobre uma onda de analfabetos. Em vez do ensino popular, que prepare a massa geral da população- elemento essencial numa democracia, em vez da instrução profissional-industrial [...] reclamaram-se universidades - já alemãs, já francesas. (BOMFIM, 1993, p. 183).

O Estado continua "conservando" esse passado educacional, seja o Estado monárquico ou republicano, ao ver do autor, esses eram governos que só visavam o poder e não o progresso. (REIS, 2006). Com isso, perpetuava-se todo tipo de crimes, iniqüidades e violações de direito. Essa realidade só seria superada se o ideal de progresso estivesse pautado na concepção de oposição ao real, para isso os revolucionários deveriam "escovar a história a contrapelo" ${ }^{\text {xviii }}$ :

[...] se não querem morrer entanguidas, mesquinhas e ridículas, têm que travar uma luta sistemática, direta, formal, conscientemente dirigida contra o passado, respeitando apenas a sociabilidade afetiva, natural entre a as populações, e os sentimentos de hombridade e independência nacional, característicos destes povos. (BOMFIM, 1993, p.161)

É nesse sentido que podemos observar que o ideal de progresso no pensamento de Bomfim estava atrelado não apenas ao elemento material, mas sim também a uma idéia de progresso que elevasse essas sociedades no seu quádruplo aspecto: econômico, político, moral e intelectual. Seria através da educação que o povo superaria o passado comum, a colonização parasitária ibérica, e a partir de então, conseguiria lutar por uma vida prospera 
livre e justa. Foi no bojo dessas relações que a instituição escravista conseguiu perdurar por muito tempo, sendo reforçada por uma população de analfabetos e por uma elite que pensava a nação de maneira superficial e vazia, por isso, não conseguiu ser criativa diante da sua realidade.

\section{Considerações finais}

A produção do conhecimento histórico, essencialmente interpretativa, visa sempre ao conhecimento do 'singular', do 'particular', ainda que recorra aos conhecimentos gerais para tanto. Aqui, argumentamos que o que se denomina de individual na história não é o fato, mas o conjunto histórico, que é mais que a soma de suas partes. Destarte, a compreensão desses conjuntos históricos individuais não pode prescindir do auxílio de abstrações conceituais, sociológicos, que guiaram o argumento central. Essa dialética entre antecipação do todo e conhecimento particular se estabelece, desse modo, duplamente. Em primeiro lugar, com o objeto do conhecimento histórico, a saber, o diagnóstico bomfiniano do "atraso" brasileiro e os desmembramentos sobre a educação e o trabalho, isto é, com a "coisa mesma", e, em segundo lugar, com a tradição de onde esse objeto nos fala, ou as interpretações relativas à Bomfim que nos guiaram.

Re-visitar a interpretação de Manoel Bomfim sobre o Brasil e a América Latina, faz parte do movimento como argumentou Doyle e Pamplona (2008) de buscar compreender as múltiplas formas pelo qual o nacionalismo, e a constituição do Estado-Nação, assumiram ao redor do mundo. A América do Sul inseriu-se nesse contexto histórico através do diálogo com as demais sociedades, onde foram, inevitavelmente, estabelecidos intercâmbios culturais (OLIVEN, 2000). Desconsiderar as relações que a formaram, seria em certa medida, deixar de fora uma parcela importante do conhecimento histórico sobre a formação nacional nessas localidades.

Manoel Bomfim, em 1905, elaborou uma interpretação relativamente original sobre a formação sócio-histórica das nações sul-americanas, isso porque preferimos tratálo enquanto integrante de uma linhagem democráticas de intelectuais brasileiros, passando por José Bonifácio e Tavares Bastos até nele transbordar. Bomfim levou em consideração o fator "econômico", que ele apontou como sendo essencial, e que perpassava a constituição dessas sociedades no mundo contemporâneo moderno. Sua idéia foi ilustrada através da metáfora "parasitismo social", que a seu ver, correspondia à investida imperialista das nações européias no Novo Mundo.

A América do Sul foi colonizada pelo mundo Ibérico, que no século XIX, entravase em decadência na Europa (BARBOSA FILHO, 2000), e que influenciou de maneira desastrosa a formação dessas sociedades. Aqui, segundo Bomfim (1993) foi instituído a dinâmica do parasitismo, a colônia produzia para reverter em lucro para metrópole. $\mathrm{O}$ parasistimo também existia no interior da metrópole, à medida que a tradição ibérica adentrou todos os setores da vida dessas comunidades. Só quem trabalhava na colônia eram os escravos, e dessa forma o trabalho ficou visto como algo não digno, infame e degradador. $\mathrm{O}$ parasitismo ibérico criou um abismo entre o trabalhador nacional e o processo de produção, na medida em que optou por instituir o trabalho escravo, que a seu ver, só beneficiava a metrópole. A superação dessa realidade, e a chegada do progresso tão desejado, pelos ideais republicanos, só se fariam através de uma educação que privilegiasse a instituição primária, protagonizasse os valores patrióticos, contidos neles, a lembrança de uma "verdadeira história", onde o elemento redentor estaria na apropriação de heróis genuinamente nacionais. 
A solução apontada por Bomfim via educação, estava em compasso com as maiorias das teses levantadas pelos intelectuais contemporâneos, como: José Veríssimo, Rui Barbosa, Joaquim Nabuco, Carneiro Leão e Oliveira Vianna (BOTELHO, 1999). Nesse sentido, a "questão educacional", no pensamento de Manoel Bomfim traduzia as inquietações de uma sociedade que precisava superar o passado escravagista e consolidar a emancipação política de uma população que chegava ser mais da metade de analfabetos.

Algumas interpretações sobre o caráter brasileiro, como no caso de Sílvio Romero, Euclídes da Cunha e Nina Rodrigues, tendiam a justificar o atraso da sociedade a partir da teoria das raças, que colocavam, desse modo, o Brasil e os paises da América do Sul, em lugar desprivilegiado na etapa da evolução social, Manoel Bomfim rejeitou essa interpretação negando completamente esse debate, pois para o nosso autor, essa idéia se sustentava sobre um fundamento falso, traduzidos por um enorme "[...] sofisma abjeto do egoísmo humano, hipocritamente mascarado de ciência barata, e covardemente aplicado à exploração dos fracos pelos fortes." (BOMFIM, 1993, p. 243). O posicionamento de Bomfim contra o racismo científico dizia respeito a sua postura "nacionalista e antiimperialista", e mais ainda, a tese defendida por ele no América Latina: males de origem refletiam os conflitos sociais entre as nações centrais e periféricas (AGUIAR, 2000). Essa discussão estava conectada com o contexto social da época, que na transição do entre século IX e XX, precisava ajustar a sociedade brasileira nos padrões modernos burgueses.

A questão que levanta a hipótese de que Bomfim foi um intelectual "a frente do seu tempo", pode ser revista a partir do argumento exposto por Reis (2006), que se utilizou do ponto de vista sugerido por Aluízio Alves Filho. Para esse autor "não existe intelectual adiantado ao seu tempo" (REIS, 2006, p. 233), e se o educador sergipano foi esquecido, não foi porque suas análises não dialogaram com seu tempo histórico, mas foi porque Bomfim formulou um contradiscurso, e dessa forma, seu pensamento se tornou incômodo em relação ao pensamento dominante, fazendo com que ele se tornasse esquecido (REIS, 2006). Assim, ao invés de caracterizá-lo enquanto um intelectual "à frente de seu tempo" (SUASSUNA; MACHADO, 2009), parece mais profícuo tratá-lo como um sujeito cuja interpretação sobre o 'atraso nacional' é conseqüência de seu olhar crítico sobre àquele contexto de produção intelectual (AGUIAR, 2000), partícipe de uma "comunidade de experiência" (ALONSO, 2000) que gestou inúmeras leituras sobre o Brasil, entre elas, a dele próprio, que, atualidade, nos auxilia a entender o que nos fez ser o que somos contemporaneamente.

Hoje, ler Bomfim parece se constituir em exercício fundamental que concebe a inextrincável relação entre as mudanças sociais e a gestação das idéias em um determinado ambiente intelectual. Ou seja, em perspectiva relativamente próxima à idéia benjaminiana, contida em suas Teses Sobre a História, Bomfim, argumentou a favor de uma história que levasse em consideração o ponto de vista dos "oprimidos", dos "excluídos", em nosso caso, talvez o próprio "brasileiro" em seu contexto latino-americano. Nesse sentido, o papel do historiador comprometido em revelar os "lampejos do passado", consiste em desvelar o fundo de barbárie contido na "história dos vencedores" (LÖWY, 2005). A análise bomfiniana, desse modo, sobre a formação nacional nas sociedades sul-americanas, denunciou a presença da "violência dos vencedores" nessas nações.

Para além de uma conclusão fechada, ressaltamos que nossas reflexões sobre a América Latina: males de origem (1905) e as teses apresentadas em torno do trabalho escravo, do racismo científico e da educação como via de emancipação do povo latinoamericano, nos conduziram, antes de tudo, para querer compreender este autor, levando em consideração a multiplicidade do seu pensamento, que nesse sentido, nos permite situar na 
mesma direção de importância de seus interpretes contemporâneos (REIS, 2006; UEMORI 2006; COSTA, 2005, 2008, GONTIJO, 2003; AGUIAR, 2000; BOTELHO, 2003), que sem dúvida, vem contribuindo para um melhor entendimento do seu pensamento, os quais traduzem a própria natureza da hermenêutica moderna, cuja idéia central talvez se encontre associada à própria tese do "inacabamento essencial da interpretação", através da obrigação, interna à atividade do pesquisador e do próprio objeto, de interpreta-se a si mesmo.

\section{Referências}

AGUIAR, Ronaldo Conde. O rebelde esquecido.Tempo, vida e obra de Manoel Bomfim. Rio de Janeiro: Topbooks, 2000.

ALONSO, Ângela. Idéias em movimento. A Geração 1870 na crise do Brasil-Império. São Paulo: Paz e Terra, 2002. Joaquim Nabuco. São Paulo: Companhia das Letras, 2007.

AZEVEDO, Célia Maria Marinho de. Quem precisa de São Nabuco. Revista Estudos AfroAsiáticos, vol. 23, nº 1,pp. 85-97, Rio de Janeiro, jan/jun, 2001.

Onda negra, medo branco. O negro no Imaginário das Elites Século XIX. São Paulo: Annablume, 2004.

BARBOZA FILHO, Rubem. Tradição e artifício. Iberismo e barroco na formação americana. Belo Horizonte: UFMG; Rio de Janeiro: IUPERJ, 2000.

BENJAMIN. Walter. Magia e técnica, arte e política: ensaios sobre literatura e história da cultura. São Paulo: Brasiliense, 1994.

BERMAN, Marshall. Tudo o que é sólido desmancha no ar. A aventura da modernidade. São Paulo: Companhia das Letras, 1986.

BOMFIM. Manoel. A América Latina: males de origem. Rio de Janeiro: Topbooks, 1993.

BOSI, Alfredo. História concisa da literatura brasileira. São Paulo: Cultrix, 1994.

BOTELHO, André. Na contracorrentente do naturalismo. Relações sociais na interpretação do Brasil de Manoel Bomfim. Revista Temáticas, no 21/22, pp. 75-100, Campinas, 2003. CALVINO, Ítalo. Por que ler os clássicos. São Paulo: Companhia das Letras, 1993.

CANDIDO, Antônio. Literatura e sociedade. Estudos de teoria e história literária. São Paulo, T. A. Queiroz, ([1965] 2000).

CANIELLO, Márcio. O Ethos Brasílico: sociologia histórica da formação nacional, 15001654". Tese (Doutorado em Sociologia). Recife, Programa de Pós-Graduação em Sociologia (UFPE), 2001.

CHACON, Vamireh. A construção da brasilidade - Gilberto Freyre e sua geração. Brasília: Paralelo 15; São Paulo: Marco Zero, 2001.

COSTA. Emília Viotti da. A abolição. São Paulo: Editora UNESP, 2008. 
COSTA, Jean Carlo de Carvalho. O problema nacional, globalização e o pensamento social no Brasil: notas sobre as implicações do "nacional" em Manoel Bomfim. Revista Política \& Trabalho, n² 22, abril, pp. 165-184, João Pessoa, Paraíba, 2005.

Nação, Estado e raça em Manoel Bomfim: a impertinência bomfiniana em torno da identidade nacional. Revista Cronos, vol. 9, $\mathrm{n}^{\mathrm{o}}$ 2, jul/dez, pp. 417-438, Natal, Rio Grande do Norte, 2008.

COSTA. Valeriano Mendes Ferreira. Vertentes democráticas em Gilberto Freire e Sergio Buarque. Lua Nova, nº 26, pp. 219-248, São Paulo, 1992.

DOYLE, Don H.; PAMPLONA, Marco Antonio (Orgs.). "Introdução”. In: Nacionalismo no novo mundo.Tradução de Waldéia Barcelos. Rio de Janeiro: Record, 2008.

GADAMER, Hans-Georg. Verdade e Método: Traços Fundamentais de uma Hermenêutica Filosófica. Petropólis: Vozes, 1997.

GONTIJO, Rebecca. Manoel Bomfim, "pensador da História” na Primeira República. Revista Brasileira de História, vol.23, no.45, pp. 129-154, São Paulo, Julho, 2003.

HEKMAN, Susan J. Hermenêutica e Sociologia do Conhecimento. Lisboa: Edições 70, 1986

LEITE, Dante Moreira Leite. O caráter nacional brasileiro. História de uma ideologia. 7 ed. São Paulo: Unesp, 2007.

LÖWY. Michael. Walter Benjamin: aviso de incêndio: uma leitura das teses "Sobre o conceito de história". São Paulo: Boitempo, 2005.

LYNCH, Cristian Edward. A primeira encruzilhada da democracia brasileira: os casos de Rui Barbosa e de Joaquim Nabuco. Revista Sociologia e Política, v. 16, Curitiba, Paraná, Agosto, 2008.

MALANTIAN, Teresa. Oliveira Lima e a construção da nacionalidade. Bauru, SP, EDUSC; São Paulo, FAPESP, 2001.

MUNANGA, Kanbengele. Rediscutindo a Mestiçagem. Rio de Janeiro: Vozes, 1999.

NABUCO, Joaquim. Campanha Abolicionista no Recife. Eleições de 1884. Brasília: Edições do Senado Federal, vol. 59, 2005.

. Balmaceda. São Paulo: CosacNaify, 2008.

OLIVEN, Ruben George." Cultura Brasileira e Identidade Nacional (O eterno retorno)". In: MICELI, Sérgio (Org.). O que ler na Ciência Social brasileira. São Paulo, ANPOCS, Sumaré; Brasília, CAPES, 2002.

ORTIZ, Renato. Identidade Nacional e Cultura Brasileira. São Paulo: Brasiliense, 1994.

PINHEIRO, Antonio Carlos Ferreira. Da Era das Cadeiras isoladas à Era dos Grupos Escolares na Paraíba. Campinas, SP: Editora Autores Associados; São Paulo:

Universidade São Francisco, 2002.

REIS. José Carlos. As Identidades do Brasil 2: de Calmon a Bomfim: a favor do Brasil: direita ou esquerda?- Rio de Janeiro: FGV, 2006.

RICOEUR, Paul. Do texto à ação. Ensaios de Hermenêutica II. Tradução de Alcino Cartaxo e Maria José Sarabando. Portugal: Rés Editora, 1986. 
ROCHA, Marlos Bessa Mendes. Matrizes da modernidade republicana. Campinas, S.P.: Autores Associados, 2004

ROHDEN, Luiz. Hermenêutica filosófica. São Leopoldo/RS: Unisinos, 2002.

ROMANELLI. Otaíza de Oliveira. História da Educação no Brasil. Petrópolis, RJ: Vozes, 2007.

ROMERO, Silvio. A América Latina: análise do livro de igual título do Dr. M. Bomfim. Porto, Livraria Chardron de Lello \& Irmão, 1906.

SALLES, Ricardo. Joaquim Nabuco. Um pensador do Império. Rio de Janeiro: Vozes, 2002.

SANTOS, Cláudia Andrade dos. Projetos sociais abolicionista. Ruptura ou continuísmo? In: Daniel Aarão Reis Filho (Org.). Intelectuais, história e política (séculos XIX e XX). Rio de Janeiro: Letras, 2000.

SCHWARCZ, Lilian Moritz. O Espetáculo das Raças. São Paulo, Companhia das Letras, 1993.

SKIDMORE, Thomas E. Preto no Branco. Raça e Nacionalidade no Pensamento Brasileiro. Rio de Janeiro: Paz e Terra, 1976.

. O Brasil visto de fora. Rio de Janeiro: Paz e Terra, 1994.

SODRÉ, Nelson Werneck. História da literatura brasileira. Seus fundamentos econômicos. Rio de janeiro: Civilização Brasileira, 1964.

SUASSUNA, Daniella de Souza Barbosa; MACHADO, Charliton José dos Santos.

Anotações sobre o pensamento de Manoel Bomfim a partir da obra América Latina: Males de Origem (1905). Revista Educação Unisinos, 13 (2), 147-151, maio/agosto. Porto Alegre, RS, 2009

VENTURA, Roberto. Estilo Tropical: história cultural e polêmicas literárias no Brasil, 1870-1914. São Paulo: Companhia das Letras, 1991.

VIANNA, Oliveira. Evolução do Povo Brasileiro. 4 ed. Rio de Janeiro: José Olympio, 1956 [1923]).

YOUNG, Robert. Colonial Desire. Hybridity in Theory, Culture and Race. London: Routledge, 1995.

UEMORI. Celso Nobrou. Explorando em campo minado: a sinuosa trajetória intelectual de Manoel Bomfim em busca da identidade nacional. Tese, São Paulo, Pontifícia Universidade Católica de São Paulo, 2006.

\footnotetext{
'Este trabalho é uma conseqüência de atividades de pesquisa que constituem o Grupo de Estudos e Pesquisas em História da Educação - GT Paraíba (HISTEDBR-PB), atualmente, sob a coordenação do Professor Antônio Carlos Ferreira Pinheiro, através da Linha de Pesquisa "Intelectuais e suas relações com a educação", sob a coordenação do professor Jean Carlo de Carvalho Costa, bem como do Grupo de Estudo e Pesquisa Sobre o Pensamento Brasileiro (GEB). Esse artigo, em particular, é um recorte derivado das discussões internas à consecução do Projeto intitulado "Intelectuais, formação nacional e educação no Brasil moderno: a 'geração de 1870' e a crítica de Manoel Bomfim" PROLICEN (2008-2009) e do Projeto intitulado "Itinerários Intelectuais, Formação Nacional e Educação no Brasil moderno: Manoel Bomfim hermeneuta do Brasil" PIVIC- UFPB (2008-2009), dos quais participam, além das co-autoras, as estudantes Sidneyde Falheiro Cunha e Dalva Regina Araújo da Silva, ambas estudantes voluntárias no PIVIC-UFPB.
} 


\begin{abstract}
ii Professor Adjunto de Sociologia no Centro de Educação (CE-UFPB), do Programa de Pós-Graduação em Educação (PPGE-UFPB) e do Programa de Pós-Graduação em Sociologia (PPGS-UFPB). E-mail: jeanccosta@yahoo.com.br

iii Estudante de Graduação e bolsista do PROLICEN - UFPB. E-mail: amanda_galvincio@hotmail.com

${ }^{\text {iv }}$ Mestranda em Educação - PPGE/UFPB. E-mail: mairalewtchuk@ hotmail.com

${ }^{v}$ Uemori (2006), em trabalho doutoral, faz alusão à semelhança dos escritos de Manoel Bomfim (1905) e Joaquim Nabuco (1883); para ele, ambos constroem suas análises sobre o "trabalho escravo" ancorados em bases econômicas e sociais. Bomfim e Nabuco "[...] revelam as reais condições dos trabalhadores - escravos e homens livres pobres-, reduzidos à máquina de produção e despojados de direitos políticos. Dirigiram sua indignação contra o despotismo da classe dominante, que possuía privilégios injustificáveis; observar-se nos textos de um e de outro a alusão á hipertrofia do Estado. Se o diagnóstico os aproxima, a causa os opõe. A escravidão, segundo Nabuco, gerou todos esses fatores. Para Bomfim, foi o parasitismo ibérico" (UEMORI, 2006. p.33-34).
\end{abstract}

${ }^{\text {vi }}$ Rebeca Gontijo (2003), por exemplo, em trabalho dissertativo sobre Manoel Bomfim, o trata não como historiador, mas sim como um "pensador da história". Segundo Gontijo, "Manoel Bomfim não pode ser considerado como historiador, no sentido de que, já em sua época, era atribuído a autores como Capistrano de Abreu (1853-19240 ou João Ribeiro (1860-1934). O primeiro, garantia sua identidade como historiador através de sua experiência no trato com fontes documentais em arquivos- o que era fundamental num momento em que almejava conferir cientificidade à história. O segundo, através de sua atividade docente e através da produção de 'reflexões mais filosóficas' sobre a disciplina, no entanto, é possível situá-lo como um 'pensador da história', recuperando seu trabalho como crítico da historiografia, disposto a fazer reflexões sobre a matéria e provocar os historiadores, num momento em que estes podiam ser identificados não por formação ou titulação, mas devido a um conjunto de práticas autodidatas e tradições intelectuais" (GONTIJO, 2003, p.134).

${ }^{\text {vii }}$ Schwarcz, por exemplo, argumenta que uma das escolas deterministas, o darwinismo social ou teoria das raças, afirmava que "essa nova perspectiva via de forma pessimista a miscigenação, já que acreditava que 'não se transmitiriam caracteres adquiridos', nem mesmo por um processo de evolução social. Ou seja, as raças constituiriam fenômenos finais, resultados imutáveis, sendo todo cruzamento, por principio, entendido como erro' (SCHWARCZ, 1993, p. 58). A partir disso, dois aspectos podem ser destacados: "enaltecer a existência de 'tipos puros' e 'compreender a mestiçagem como sinônimo de degeneração não só racial como social".

viii Schwarcz (2003) fez menção em seu livro, hoje clássico, sobre o papel exercido no pensamento brasileiro por esse arcabouço teórico produzido na Europa dos novecentos e Uemori (2006), mais recentemente, em Tese de Doutorado, vai além em sua análise da utilização em larga escala do darwinismo social, como um dos pressupostos explicativos utilizados pelos intelectuais do fim do século XIX e inicio dos XX. Uemori analisa o uso interno desse "paradigma" no pensamento brasileiro e, em particular, no "América Latina" de Manoel Bomfim, argumentando que o intelectual sergipano, ainda que embebido em uma "comunidade de experiência" (ALONSO, 2002) similar ao seu conterrâneo, Silvio Romero, apreende, assimila e interpreta tal arcabouço de forma essencialmente distinta.

ix Joaquim Nabuco (1849-1910), em seu "Balmaceda", obra hoje clássica e, na verdade, pouco conhecida, reúne um conjunto de artigos escritos por Nabuco publicados em livro em 1895, cuja análise é a crise política do presidente chileno José Manuel Balmaceda (1840-1891), aproximada por Nabuco a fim de discutir a própria "crise" no Brasil de então impulsionada pela instabilidade política e pela intervenção estrangeira tranduzida através da Revolta da Armada de 1893 no Governo de Floriano Peixoto. Na verdade, o objetivo de Nabuco, além desses, era trazer à baila a "Questão da América Latina", isso porque, para ele, "A América do Sul, seja lícito dizer de passagem, e sem aplicação ao Chile, não teve ainda um historiador; não existe esboço crítico completo da sua existência política; ninguém extraiu ainda do vasto material avulso enterrado em suas capitais longínquas um arcabouço de história" (NABUCO, 2008). Comparativa, o texto bomfiniano segue na mesma perspectiva do "Balmaceda", aproximando o "nacional" de questões, na verdade, constitutivamente continentais.

${ }^{x}$ A "lei da hereditariedade" na obra de Manoel Bomfim recebeu a influência dos autores canônicos como Charles Darwin, Ernest Haeckel e Theodore. Ribot. A hereditariedade conectava-se as noções de necessidade, conservação e estabilidade. Ribot pensou os seres vivos sob a ação da hereditariedade (conservação indefinida) e da variação, a junção das duas torna possível compatibilizar modificação 
morfológica e psicológica; Haeckel abordou o assunto, afirmando que as duas forças antagônicas atuavam sobre os organismos: hereditariedade (força centrípeta ou interna, que conserva) e a adaptação (força centrifuga e externa). (UEMORI. 2006).

${ }^{x i}$ Em 1999, Ronaldo Conde Aguiar defendeu na UNB Tese de Doutorado sobre a vida e obra do autor citado, sendo considerada a Melhor Tese de Doutorado no I Concurso Brasileiro CNPQ-ANPOCS de Obras Científicas e Teses Universitárias em Ciências Sociais, tendo o seu trabalho publicado no ano posterior sob o título "O Rebelde Esquecido. Tempo, vida e obra de Manoel Bomfim". Cremos ser relevante o apontamento, tanto para salientar a importância de Manoel Bomfim, agora não mais esquecido.

xii Outro autor consensualmente mencionado na literatura, que comporia com Manoel Bomfim esse "contradiscurso" à predominância hegemônica relativa às explicações sobre a raça e sobre o Estado brasileiro, seria Alberto Torres. Torres, baseando-se em teorias recentes no pensamento social europeu, especialmente no culturalismo emergente de Franz Boas, central futuramente na obra de Gilberto Freyre, rejeitou, como Bomfim, a redução do problema nacional à questão racial, alertando que, na verdade, esse "não está na diversidade racial, mas sim na inadequação entre a realidade do país e as instituições tomadas de empréstimo das nações antigas, o que resulta na alienação da realidade nacional" (MUNANGA, 1999, p. 61), o que o leva a atribuir importância essencial ao papel da educação, elemento também visto no diagnóstico de Bomfim. A respeito das impossíveis relações entre miscigenação e nacionalidade afirma: "Nenhum dos povos contemporâneos é formado de uma raça homogênea e isto não lhe impediu de formar uma nação, moral, política e socialmente [...]. Se os indígenas, os africanos e seus descendentes não puderam 'progredir e aperfeiçoar-se' isto não se deve a qualquer incapacidade inata, mas ao abandono 'em vida selvagem ou miserável, sem progresso possível” (TORRES, 1914 apud MUNANGA, 1999, p. 61).

xiii Oliveira Vianna, por exemplo, ao tratar da questão étnica, baseava muitas vezes o seu argumento na estatística, considerada por ele "a consciência das sociedades". Vianna afirmava que a anteriormente negada diversidade étnica estava a ser transformada, gradativamente, através do "refinamento da raça" (VIANNA, 1956 [1923], p. 186), que era, por sua vez, produto de uma "lenta elaboração histórica" (VIANNA, 1956 [1923], p. 169), elaboração essa auxiliada pelo papel do movimento imigratório europeu no aumento do "coeficiente da raça branca" (VIANNA, 1956 [1923], p. 170).

${ }^{\text {xiv }}$ É interessante observar que em Sílvio Romero essa "paixão" transbordava e talvez devido a ela tantas contradições apontadas em sua obra, cujo objetivo era apenas elaborar uma interpretação que fosse prospectiva no sentido de forjar os meios para um desenvolvimento apropriado da nação brasileira. Euclides da Cunha, na esteira de Sílvio, embora também amparado por teorias contemporâneas a ele, não pode ser considerado um autor no qual a paixão se encontre ausente; ao contrário, e os seus intérpretes confirmam: "Há uma paixão do real em Os Sertões que transborda dos quadros do seu pensamento classificador; e uma paixão da palavra que dá concretíssimos relevos aos momentos mais áridos da sua engenharia social" [...] Os Sertões são um livro de ciência de paixão, em que alternam a certeza do fim das 'raças retrógradas' e a denúncia do crime que a carnificina de Canudos representou” ( BOSI, 1994, pp. 308, 309).

${ }^{\mathrm{xv}}$ Sem dúvida, é bastante estimulante ressaltar que os textos desses autores utilizados por Bomfim para dar sustentação teórica ao seu livro são extremamente contemporâneos a ele, haja vista que ele iniciou a "A América Latina" em 1903. O texto de Zaborovski, por exemplo, trata-se de uma conferência na Escola de Antropologia de Paris realizada em novembro de 1902, enquanto o livro citado de Topinard é datado de 1900, no qual esse autor afirma: "Há arianos na lingüística, mas não há raça ariana; assim como há franceses, sob o ponto de vista de língua, mas antropologicamente não há raça francesa" (TOPINARD, 1900, p. 229 apud BOMFIM, 1993 [1905], p. 249). Isto reforça o potencial de Bomfim em identificar e compreender a existência na época de um discurso distinto e os interesses a que o conhecimento científico encontra-se inevitavelmente atrelado. Diz Bomfim em relação a um determinado tipo de academicismo: "Desprezemos dissertações e preceitos formulados a distância; demos férias aos doutores e mais oráculos - economistas e sociólogos que não se cansam de disparatar, doutrinando a nosso respeito; esqueçamo-los e voltemo-nos para o princípio" (BOMFIM, 1993 [1905], p. 321). Como se verá, comparando-o à argumentação de Oliveira Vianna (1883-1951), cuja obra é contemporânea às transformações empreendidas pelo clima da Semana de Arte Moderna em 1922, duas décadas após essa obra de Manoel Bomfim, entende-se a sua importância na atualidade. Os "homens de 22" (BOSI, 1994), na esteira de Bomfim, rompem com a idéia de nossas supostas ou reais "deficiências" e as reinterpretam como superioridades (CANDIDO, 2000 [1965], p. 120).

${ }^{x v i}$ De fato, alguns intelectuais criaram esquemas explicativos se utilizando da instituição escravagista como ponto central para propor reformas "para além da abolição", que justificassem a "libertação do negro como, por exemplo, implementação do trabalho livre, "universalização da instrução" e a "democratização do solo", 
leia-se reforma agrária, que, atrelados a esses, impulsionariam o desenvolvimento e o progresso da civilização. Segundo Costa (2008), em uma análise hoje clássica da Abolição e de alguns de seus "protagonistas", a historiografia oficial privilegiou nomes como Luiz Gama (1830-1882) e André Rebouças (1838-1898), e entre esses, aquele que mais a ela foi associada notoriedade, sem dúvida, Joaquim Nabuco (1849-1910). Nabuco, além de publicar em 1883, O abolicionista, livro aquele que, em definitivo, trouxe a abolição à agenda política nacional e o tornou peça-chave na libertação dos escravos no país (ALONSO, 2007), concedendo-lhe reconhecimento histórico. Nabuco, entre tantos outros que constituíam a intelligentsia nacional, era descendente de uma importante oligarquia pernambucana, que por influência o levou ao parlamento como deputado de Pernambuco em 1878 e, conduzido por várias oscilações e contradições, iniciou a gestação de sua trajetória intelectual e, especialmente, política (ALONSO, 2007). Podemos destacar, também, o jovem baiano Rui Barbosa (1849-1923), ambos pertencentes ao partido liberal e, àquele momento, próximos do ponto de vista político, logo se colocaram nos debates políticos, que incluíam modernização democrática, a abolição da escravatura, federalismo e a república (LYNCH, 2008).

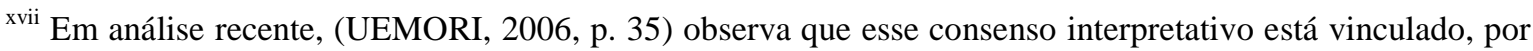
exemplo, a algumas teses presentes em Joaquim Nabuco, quando, por exemplo, o "abolicionista referiu-se várias vezes ao caráter dócio e pacifico do 'brasileiro', com o objetivo de afirmar que a abolição deveria ser conduzida pacificamente, ou seja, sem o perigo dos conflitos políticos”. Aqui, creio que é preciso relativizar a afirmação de Uemori (2006), isso porque parece, do nosso ponto de vista, haver dois elementos distintos em Joaquim Nabuco: por um lado, a defesa de Nabuco, conseqüência de seu liberalismo e de sua defesa da monarquia parlamentar, de que a "mudança" e a implementação de "reformas radicais", não deveriam ser acompanhadas de "radicalismo" e "violências", e não porque isso era uma derivação de uma suposta concepção "essencialista" de sujeito, muito similar a vertentes do evolucionismo social em voga à época, ao qual ele nunca esteve próximo, não por acaso, embora contemporâneo de Silvio Romero e Tobias Barreto, jamais se associou ao que Silvio denominou de "Escola do Recife"; por outro lado, o seu olhar sobre a escravidão não sempre foi de "horror", defendendo que a "obra da escravidão" apenas inexistiria de fato a partir da "democratização do solo" (reforma agrária) e o "derramamento da instrução" (NABUCO, 2005[1884]). No entanto, talvez o argumento possa ser relativamente associado ao também pernambucano Gilberto Freire, que em Casa Grande \& Senzala (1993), faz uma interpretação da vida social do Brasil colônia, ressaltando seu processo dinâmico, "plástico", adaptativo e, especialmente, "democratizante", não conflitual. (COSTA, 1992).

xviii Para Walter Benjamin "escovar a história contrapelo" consistiria em capturar os relampejos do passado, e no presente liderar "a ação revolucionária" contra injustiça de classe, e aos esquecidos soterrados pela história da tradição e do conformismo (LÖWY, 2005).

Artigo recebido em: 02/01/2010

Aprovado para publicação em: 05/03/2010

Revista HISTEDBR On-line, Campinas, n.37, p. 183-204, mar.2010 - ISSN: 1676-2584 